\title{
Diversity of Neuromuscular Disorders in Referred Patients to Electro Diag- nostic Units of Yazd City
}

\author{
Ahmad Zeinali ${ }^{1}$, Abolghasem Rahimdel ${ }^{1}$, Reza Boostani ${ }^{2}$, Ali Mellat ${ }^{1,}$ \\ ${ }^{1}$ Neurology Department, Shahid Sadoughi Hospital, Yazd University of Medical Science, Yazd, IR Iran \\ 2 Neurology Department, Qaem Hospital, Mashhad University of Medical Science, Mashhad, IRIran \\ * Corresponding Author: Ali Mellat, Shahid Sadoughi Educational and Research Center, Yazd, IR Iran. Tel: +98-3518224001, Fax: +98-3518224100, E-mail: ali_ \\ mellat@ssu.ac.ir.
}

Keywords: Electrodiagnosis; Neuromuscular Diseases; Carpal Tunnel Syndrome

\section{Dear Editor,}

Electrodiagnostic tests are electrical technologies for evaluating the body's neurophysiology and used as a complementary method for diagnosing the neuromuscular disorders. These tests are commonly used to diagnosis these disorders: Anterior horn cell disease, Polyneuropathy, Mononeuropathy, Plexopathy, Radiculopathy, Polyradiculoneuropathy, Neromuscular junction and Muscular disorders $(1,2)$. Because the prevalence and demographic features of disorders referred to electrodiagnosis departments are undetermined, this study was performed. People enrolled the study were patients whom were referred to electrodiagnosis units in Yazd from June 2009 to June 2011.Studied variables were: age, sex and test results included: normal, carpal tunnel syndrome (CTS), cervical and lumbar radiculopathy (Cer. Rad, Lum. Rad.), trauma, peripheral neuropathy (P.N.), nerve entrapment (N.E.), myopathy, motor neuron disease (M.N.D.), myotonia, neuro-muscular junction (N.M.J) disorders (myasthenia). In two years consecutive study, EMG-NCV findings of 2933 patients were analyzed. 1651 patients were females and 1282 patients were males which female gender was more significantly $(\mathrm{P}<0.001)$. Patients' mean age was $43.2 \pm 16.4$ which 1805 patients were more than 40 and 1128 were under 40 years old $(\mathrm{P}<0.001)$. CTS, lumbar and cervical radiculopathy and peripheral neuropathy were more in patients over 40 years old and trauma, motor neuron disease, myotonia and myasthenia were more in patients under 40 years old significantly $(\mathrm{P}<0.001)$. Numerous studies emphasized the more prevalence of CTS in patients over 40 years because of osteoarthritis and diabetes mellitus (3-5). More normal reports in patients over than 40 yeras old are may be due to rheumatologic disorders, neuromuscular pain with articular, tendonal or muscular origin in which may lead to false diagnosis and refer normal patients for EMG-NCV (6-8). Normal variable and CTS were more in females and cervical radiculopathy, trauma, nerve entrapment and myotonia were more in males significantly $(\mathrm{P}<0.001)$. Several studies indicate more prevalence of CTS 3 to 7 times in females (3-5). In our study this ratio was 6.5/1. In this study cervical radiculopathy was more prevalent in men like other studies $(P=0.024) 9.32 .3 \%$ of reports were normal which may be due to high prevalence of soft tissue disorders, muscular pain around shoulder and pelvic griddles such as bursitis, tendonitis and myofacial pain which may be misdiagnosed as radicular pain or other peripheral diseases (6-8). So obtaining precise history and performing complete general and neurologic examination could lead to decrement the referring rate of patients with diseases other than motor unit involvement lead to lowering cost of EMG-NCV for health and treatment system (Table 1).

\footnotetext{
-Article type: Letter; Received:15 Jan 2012, Revised: 27 Nov 2012, Accepted: 20 Jan 2013; DOI: 10.5812/ircmj.4169

Please cite this paper as:

Zeinali A, Rahimdel A, Boostani R, Mellat A. Diversity of Neuromuscular Disorders in Referred Patients to Electro Diagnostic Units of Yazd City. Iran Red Cres Med J. 2013; 15(3):274-5. DOI: 10.5812/ircmj.4169

Copyright ( C 2013, Iranian Red Crescent Medical Journal; Published by Kowsar Corp.

This is an Open Access article distributed under the terms of the Creative Commons Attribution License (http://creativecommons.org/licenses/by/3.0), which permits unrestricted use, distribution, and reproduction in any medium, provided the original work is properly cited.
} 
Table 1 Prevalence Distribution of Findings Based on Age and Sex

\begin{tabular}{|c|c|c|c|c|c|c|c|c|c|c|c|}
\hline & \multicolumn{11}{|c|}{ Findings } \\
\hline & Normal & CTS & Lum. Rad & Cer. Rad & Trauma & P. N & N.E & MND & Myopathy & Myotonia & N.M.J \\
\hline \multicolumn{12}{|l|}{ Age, y, No. } \\
\hline$<20$ & 83 & 9 & 9 & 2 & 60 & 30 & 18 & 16 & 14 & 6 & 2 \\
\hline $20-29$ & 177 & 30 & 13 & 6 & 89 & 18 & 29 & 5 & 6 & 7 & 3 \\
\hline $30-39$ & 233 & 117 & 41 & 11 & 72 & 16 & 13 & 5 & 11 & 2 & 2 \\
\hline 40-49, No. & 260 & 228 & 89 & 24 & 70 & 31 & 21 & 10 & 12 & 2 & 1 \\
\hline 50-59. & 109 & 216 & 73 & 29 & 22 & 47 & 19 & 3 & 11 & 3 & 0 \\
\hline$>60$ & 85 & 129 & 119 & 31 & 21 & 85 & 17 & 7 & 3 & 1 & 0 \\
\hline Pvalue & 0.205 & $<0.001$ & $<0.001$ & $<0.001$ & $<0.001$ & $<0.001$ & 0.782 & 0.007 & 0.04 & 0.002 & 0.007 \\
\hline \multicolumn{12}{|l|}{ Sex, No. } \\
\hline Male & 422 & 96 & 170 & 60 & 261 & 125 & 70 & 25 & 24 & 16 & 4 \\
\hline Female & 525 & 633 & 174 & 43 & 73 & 102 & 47 & 21 & 33 & 5 & 4 \\
\hline Pvalue & $<0.001$ & $<0.001$ & 0.829 & 0.024 & $<0.001$ & 0.127 & 0.026 & 0.555 & 0.233 & 0.016 & 1 \\
\hline Total, No. (\%) & $8(0.3)$ & $21(0.7)$ & $57(1.9)$ & $46(1.6)$ & $117(4)$ & $227(7.7)$ & $334(11.4)$ & $103(3.5)$ & 344 (11.7) & $729(24.9)$ & $947(32.3)$ \\
\hline
\end{tabular}

\section{Acknowledgements}

None declared.

\section{References}

1. Dumitru D, Amato AA, Zwarts MJ. Electro Diagnostic Medicine. Hanley \& Belfus; 2002.

2. Kimura S, Naito A, Tuzi S, Saito H. A (13)C NMR study on [3-(13)C]-, [1-(13)C]Ala-, or [1-(13)C]Val-labeled transmembrane peptides of bacteriorhodopsin in lipid bilayers: insertion, rigid-body motions, and local conformational fluctuations at ambient temperature. Biopolymers.2001;58(1):78-88

3. Gelfman R, Melton LJ, 3rd, Yawn BP, Wollan PC, Amadio PC, Stevens JC. Long-term trends in carpal tunnel syndrome. Neurology.2009;72(1):33-41
4. Gomes I, Becker J, Ehlers JA, Kapczinski F, Nora DB. Seasonal distribution and demographical characteristics of carpal tunnel syndrome in 1039 patients. Arq Neuropsiquiatr.2004;62(3A):596-9

5. Tay LB, Urkude R, Verma KK. Clinical profile, electrodiagnosis and outcome in patients with carpal tunnel syndrome: a Singapore perspective. Singapore Med J.2006;47(12):1049-52

6. Cannon DE, Dillingham TR, Miao H, Andary MT, Pezzin LE. Musculoskeletal disorders in referrals for suspected lumbosacral radiculopathy. Am J Phys Med Rehabil.2007;86(12):957-61

7. Cannon DE, Dillingham TR, Miao H, Andary MT, Pezzin LE. Musculoskeletal disorders in referrals for suspected cervical radiculopathy. Arch Phys Med Rehabil.2007;88(10):1256-9

8. Qerama E, Kasch H, Fuglsang-Frederiksen A. Occurrence of myofascial pain in patients with possible carpal tunnel syndrome - a single-blinded study. EurJ Pain.2009;13(6):588-91 